\title{
Building Africa's Homegrown Humanitarian Systems: Restoration as an Alternative to Localization
}

\author{
Oheneba A. Boateng * \\ Global Public Policy Institute, Berlin, Germany
}

Many humanitarian actors now recognize that it is crucial to build response structures on the basis of the norms, knowledge, and institutions of those affected by disasters. Currently, this concept has been captured through the term localization. However, the use of localization both as a term and process has so far been done without critical reflection on the traditional meaning of the term, and the impact of its historical application. It has also come about without proper historicization of the broader localization process and how this related to historical antecedents. This paper problematizes localization as a troubled term that describes a concept that has been applied in the past to help erode the homegrown humanitarian initiatives that Africans started. It draws attention to how international humanitarian actors established themselves in Africa as a process of

OPEN ACCESS

Edited by: Kristina Roepstorff, Ruhr-University Bochum, Germany

Reviewed by:

Samantha Melis, ISS/EUR, Netherlands

Sasikumar S. Sundaram, American University, United States

*Correspondence: Oheneba A. Boateng oboateng@gppi.net

Specialty section: This article was submitted to Peace and Democracy,

a section of the journal Frontiers in Political Science

Received: 17 May 2021 Accepted: 16 August 2021 Published: 08 September 2021

\section{Citation:}

Boateng OA (2021) Building Africa's Homegrown Humanitarian Systems: Restoration as an Alternative

to Localization.

Front. Polit. Sci. 3:711090. doi: 10.3389/fpos.2021.711090 localization which eventually contributed to the erosion of the homegrown initiatives that they interacted with. Given its historically erosive effects on homegrown initiatives, localization, the paper argues, is a troubled term that cannot be redeemed or repurposed for the current attempt to build humanitarian action on homegrown structures. A more reflective and appropriate term is restoration, which not only recognises this history of erosion, but repairs historical mistakes, and ensures that homegrown structures are built in a sustainable manner that avoids a repeat of those mistakes. Restoration in practice should be based on self-determination, and will depend on the leadership of African states, their ability to create a conducive environment for homegrown NGOs to thrive, and the successful synergies they build with other restoration processes across the continent. International actors will have to intentionally reconcile themselves with their erosion footprints, exercise restraint, and scale back their involvement so that local actors can gain the space to evolve. The paper concludes that all this starts with the ability of those leading the process to build homegrown structures to imagine an alternative humanitarian future.

Keywords: Africa, homegrown, localiaztion, erosion, restoration

\section{INTRODUCTION}

In recent years, the need for humanitarian responses to be dictated by the agency of affected countries and societies has dominated discourse in the field. This has been captured by the concept of localization which received a burst of enthusiasm, including the 2016 World Humanitarian Summit and the Seven Dimensions of localization that are meant to help the field monitor progress (Van 
Brabant and Patel 2018). However, critical questions remain; it has become clear that the humanitarian community is still looking for a clear path forward. For instance, most signatories missed the Grand Bargain's 2020 target of giving homegrown actors control over $25 \%$ of global humanitarian funding (Metcalfe-Hough et al., 2020, 4). In some cases, funding dropped to pre-Grand Bargain levels, while others have complained over the lack of systems to hold international actors accountable to their commitments (Ncube 2020). Progress on localization, therefore, is yet to match the initial enthusiasm.

Several reasons have been proposed to explain this slow progress, including the lack of strategy, failure to scale small achievements, restrictive donor policies, and the often cited limited capacities of homegrown actors to lead the process (Metcalfe-Hough et al., 2020). However, as contended in this paper, there are two fundamental obstacles to the current agenda, and both are conceptual in nature. The first is that the term "localization" is not clearly defined. As a paper recently argued, "the current debate remains strikingly undertheorized with a number of key conceptual questions still unaddressed" (Roepstorff 2020, 2). A second conceptual obstacle comes from the lack of historicization. The humanitarian community is found to be locked in a state of "perpetual present" (Borton 2016, 202). This means that agenda like localization are implemented as if there is no history to them. While localization needs practical ways to move forward, the undertheorizing and lack of historicization require the field to clearly conceptualize what it is doing. Such revision is crucial because concepts are used to structure principles as well mobilize and distribute resources, meaning they have practical implications (Taithe and Borton 2016, 221). Making progress therefore must start with a proper understanding of what localization is and the limits of its utility.

Responding to this need for historicisation and conceptual revision, this paper argues that while it is imperative that the agency and institutions of affected communities dictate the course of humanitarian response, localization is a historically inaccurate term to capture the process. This argument is based on evidence that since 1960s there have been homegrown African processes that got eroded partially through processes of localization in the original meaning of the term. By proposing the concept of "restoration", the paper aims to question the appropriateness of the term localization, invite humanitarian actors to think with historical consciousness, and pushes international and homegrown actors to be aware of, acknowledge, and learn from how their interactions have contributed to the erosion of homegrown humanitarian initiatives in Africa. The paper concludes that "restoration" is the historically appropriate concept that based on the principle of self-determination, African states must apply to guide the process of building self-sufficient homegrown systems.

\section{METHODS}

This paper is related to a forthcoming monograph that provides a genealogical account of the homegrown humanitarian regime that the Organisation of African Unity (OAU) and its successor African Union (AU) have attempted to build since the 1960s and how this structure has been eroded by internal factors and through interactions with UN agencies and INGOs. As such, the methods used in this paper reflect those of the broader project. At the core of the study is the question of the agency of affected people, specifically about how this evolved historically and how to make this the institutional and operational basis of humanitarian action as part of ongoing reforms. This paper focuses specifically on the nature of relations that developed between international and African actors around the continent's refugee problems. While the relationship has evolved into other directions, it was around the refugee problem that most of the tensions that form the basis of the study developed.

For this paper, these questions are approached through several methods. One is a review of literature on how the current localization agenda treats key issues like the agency of homegrown actors, physical territory, and the selfdetermination of affected people. Most of the literature reviewed were published over the past decade and were selected through online searches from the websites of journals and humanitarian organizations. This timeline was chosen because of their proximity to the current localization agenda which is the subject of critique in this paper.

For the analysis and main argument, the paper draws on two additional sources which were collected over the past 5 years as part of the data collection for the monograph project. They are publications from the 1970s and 1980s that studied relations between international humanitarian actors and African states and societies. Also used are primary documents from the archives of the AU that cover mainly the OAU period and provide insight into interactions between African actors and their international partners. With both sources, the paper accounts for Africa's homegrown initiatives and how interactions with international actors helped erode these processes. Based on these methods, the paper adapts the concept of "restoration" from the field of ecological planning to argue that the process of building a humanitarian system based on the values and institutions of homegrown actors must be conceptualized not as localization, but as the restoration of the previously truncated process of homegrown initiatives.

\section{LOCALIZATION OF HUMANITARIAN ACTION}

Many in the international humanitarian community now agree that humanitarian responses should be built on the values and institutions of those affected by the disasters. One way the field has tried to think about this is through the concept of localization of humanitarian action. In the current discourse, localization defies conclusive definition, but has been described from several perspectives like the recruitment of indigenous staff, respecting local norms, capacity strengthening, increasing funding, joint coordination, and giving leadership to homegrown organizations (Wall and Hedlund 2016; Barbelet 2018). Some have also hinted at the need for structural localization, where the humanitarian 
system will be "turned on its head" (Robillard et al., 2020, 12-13,; Gingerich and Cohen 2015). A longer standing structuralist argument is that by reducing dependence on today's major donors, the humanitarian community can use localization as a mechanism to adapt to the post-Western world (Kent 2011). In short, localization of humanitarian action is a concept that is still searching for a clear definition.

A related challenge is that localizers are struggling to define the relationship of localization to space. As said in a recent paper "little has been said about the concept that forms the basis of the debate-namely, the notion of the local" (Roepstorff 2020, 2). There is an argument that though the local traditionally carries connotations of physical territory, the intersectional nature of today's UN agencies and INGOs that are simultaneously "international" by their Western origins, and "local" through their country and field offices in the South make a spatially-based understanding of the local untenable (Robillard et al., 2020, 10). According to others, this confusion gets worse in disaster situations where the mixing of foreign and homegrown organizations makes distinctions difficult (Robillard et al., 2020, 5; Erdilmen and Ayesiga Sosthenes, 2020, 7). Given the centrality of space to humanitarian action, a lack of definition detracts from the localization agenda.

A section of the literature has proposed deterritorialization of the local as the solution to the confusion over physical space. Through the idea of "critical localism", some suggest that the local needs reconceptualization as a set of historically constructed ideas, practices and flows that inhabit the complex interactions among aid donors, humanitarian organizations, and recipient communities (Mac Ginty 2015, 842; Roepstorff 2020, 9). What is dreaded in critical localism is that maintaining the international-local binary risks perpetuating negative stereotypes of both donors and recipients (Roepstorff 2020, 9). According to one proponent, critical localism "is able to accommodate post-territorial views of locality, in which populations move and the meanings attached to land change" (Mac Ginty 2015, 849). This way, critical localism creates an ideal world where international and homegrown actors operate on supposedly democratic and egalitarian bases.

Besides conceptual challenges, localization faces certain practical obstacles. While praised for their unique advantages, homegrown actors are considered to lack adequate capacity to take on and sustain the responsibility of planning and delivering aid. Relatedly, there is fear that the withdrawal of international actors would worsen humanitarian needs. Donor policies that prohibit direct funding of homegrown actors are also problematic, just as those who consider localization as a zerosum game in which homegrown gains translate as losses to internationals, which makes the latter hesitant to devolve power down the rungs (Barakat and Milton 2020, 150, Roepstorff 2020). Another is the lack of a mechanism for assessing and holding organizations accountable to their localization commitments (Ncube 2020). There is also a lack of clarity about who takes charge of localization. Though localization is approached as a joint project among the UN, INGOs, countries that give aid, and affected countries (Barakat and Milton 2020; El Taraboulsi et al., 2016), a clear leadership is still lacking. Significant progress, in some cases, have been made under state leadership (Baseisei et al., 2019; Robillard et al., 2020). However, these are not embedded in a fieldwide strategy.

It has been argued that instead of elevating the agency of affected people, localization, given these challenges, might end up perpetuating the status quo of UN, Western donors, and INGO dominance (Ncube 2020). What these challenges point to is that despite operating with the concept of making local actors more active in humanitarian response, localization has no concrete endgame. Everyone has an idea of what the localization of humanitarian action should do, but no one knows how it should look like when it is completed. In other words, someone needs to take charge of the process of instituting the values and institutions of affected people as the basis of humanitarian action.

Contributing to explaining why such confusion persists, this paper contends that the challenges of localization are significantly conceptual. Specifically, it draws attention to the misapplication of the term localization and the lack of historicization as the main factors that account for this confusion over what building homegrown systems should look like. The first is that localization as used in the humanitarian field has departed from its traditional definition across multiple academic and policy fields as the process through which foreign templates are adapted to local spaces. In norm research, Acharya defines it as "the active construction of foreign ideas by local actors, which results in the former developing significant congruence with local beliefs and practices" (Acharya 2004, 245). To another scholar, localization "explains how transnational norms are contested, adapted, and incorporated into a new context" (Capie 2008, 639).

Similar definitions are used in practice fields as diverse as international marketing, (Rutihinda and Elimimian 2003), international business (Schaler 2009), and from academic studies of the globalization-localization divide (Schuerkens 2003; Robertson and White 2008). Two main points are central to the definitions of localization from all these fields. One concerns agency, specifically that localization processes can be driven by either homegrown actors that are resident in the receiving context, or by external entrants (Acharya 2004, 245; Schaler 2009, 211). However, the definitions agree that regardless of who leads the process, the ideas to be localized are imported; they do not originate from the receiving context. The failure to broadly articulate these peculiarities in the current debate on the localization of humanitarian action has increased the confusion. It has left the term open to interpretation, hence the multiple, but often endless attempts to define what it is. However, this paper argues that to properly build humanitarian action based on homegrown structures, the suitability of the term localization needs to be critically questioned, especially in how its traditional meaning guided historical processes.

This is important because as the second source of confusion, many humanitarian actors fail to properly historicize their discourse and practice of localization. This observation emanates from arguments that the humanitarian field is averse to learning from its own history. It is argued that humanitarian agencies live in a state of "perpetual present" where aid is dictated 
by the urgency of responding to current disasters with little capacity or interest in history and its lessons (Borton 2016, 202). However, as explained later in the paper, critics believe that the humanitarian system must face and learn from its own historical relationship with colonialism before reform processes can proceed. The rest of the paper will argue that once taken seriously as they should, the traditional definition of localization and historicization lead to the conclusion that localization of humanitarian action as a process of adapting international templates into local contexts has already occurred and in a way that helped erode homegrown processes. It implies that "localization" is a historically inaccurate term to drive the process of building homegrown structures as the bases of humanitarian action. An alternative concept, therefore, becomes necessary.

None of this is meant to question the idea of building homegrown structures as the basis of humanitarian action, neither is it meant to trivialize the efforts of international humanitarian actors and their staff that are dedicated to this goal. On the contrary, this paper is written on the conviction that building homegrown structures is timely and still justified on three main grounds. As outlined by one study, these include normative, which means localization is necessary because is the right thing to do, instrumental, as it aims to tap into the advantages that homegrown organizations bring, and emancipatory as justified by the need to free homegrown actors from the constraints of structural inequalities and strengthen autonomous capacities (Brown et al., 2014, 11-12). All three are considered equally important. That said, a critical questioning of localization in this process is necessary because, as noted above, terms are used to structure actions and guide the distribution of resources. By proposing restoration as an alternative to localization, therefore, the objective of this paper is to help humanitarian actors approach the process of building homegrown structures in a more clinical, efficient, and historically accurate manner.

\section{AFRICAN HOMEGROWN INITIATIVES}

One of the ways to challenge the use of localization, is to retrace the largely ignored history of homegrown humanitarian processes in Africa. Homegrown processes describe the norms, structures, and resources that people who are affected by a certain problem mobilize to help themselves (Okereke and Agupusi 2015). It is a bottom-up process that people start in physical spaces where government interventions have failed or are non-existent. The normative basis of homegrown initiatives is self-determination which means the capacity of an actor or a collective to make their own decisions and choices on issues that affect them. It means that homegrown processes are neither externally induced nor controlled but emerge and survive solely on the initiative and persistence of those affected by the problem in those territories (Ezeanya-Esiobu, 2017; Okereke and Agupusi, 2015). Homegrown initiatives, therefore, are expressions of agency by those who want to solve their own problems.
Historicizing African homegrown initiatives starts from the point that actors across the continent have historically organized to provide relief to disaster victims. Precolonial societies drew on communitarian values to integrate economies of care into everyday social life, and before the 1960s, African actors organized mutual help within and across colonies (Harris 1987). Structures beyond family and community units expanded with the work of European missionaries that deployed colony-wide social welfare as an evangelistic tool, followed by schemes that colonial authorities designed to assist and protect settlers (Daley 1989; Mubiala 1989). As disasters overwhelmed traditional economies of care, returnees, local communities, and the budding independence movements created welfare schemes to help the displaced (Harris 1987). However, as resources remained under the control of oppressive colonial governments, assistance through such initiatives was limited. This points to the key role colonialism played both as a cause of forced displacement and a structural constraint on African initiatives (Omeje 2015; Tejumola 2017). Consistent with the idea that homegrown initiatives are created to fill a vacuum, Africa's humanitarian mobilization beyond community and smaller social units started as a corrective process to clean up the excesses of colonial policies.

The 1960s marked the beginning of more independent action by the new states and African civil society. Homegrown processes during this period were practiced within local physical territories, the refugee camp, community, liberated territories, and the independent country, all of which represented different manifestations of the local. Multiple actors operated in these localities, key among them anti-colonial political parties and liberation movements which sometimes as de facto governments, created welfare schemes for those in liberated territories (Shepherd 1974, 77-78; Melber 2002, 164-6). As independent states reorganized space for social and political transformation, the local became the refugee camp, town, national, and the regional level as governments started to cooperate through continental organizations.

Refugees and host communities also started initiatives at the subnational level, especially in Eastern, Central, and Southern Africa where liberation wars displaced hundreds of thousands of Africans across colonies. Motivated by self-reliance, refugees undertook subsistence farming and managed their own social amenities under the leadership of all-refugee committees. In Tanzania and Uganda, this do-for-self system made them largely independent of host communities, with one observer concluding that "the established rural refugee settlements have attained a level of development and self-reliance comparable to that of the nationals in the neighbourhood" (Gasarasi 1984, 49). Community-based organizations and Africanized religious bodies created their own aid programs or inherited the welfare schemes of departed European missionaries, adding to existing capacities in country (Tandon 1984, 268). As liaisons between local government, international actors, and refugee settlements, community organizations became pillars of subnational initiatives.

Simultaneous to subnational processes, refugee-hosting states motivated by humanitarian and security goals were 
trying to play coordinating roles. As the refugee population exploded, African states found it difficult to ignore the economic, political, and security concerns it raised, and started using state structures to directly regulate and exercise oversight of refugee settlements and humanitarian actors (Daley 1989, 214). Starting in the 1960s, the perilous and transnational nature of the refugee problem forced the new states to start searching for collective solutions through the OAU, adding a continental dimension to homegrown initiatives. From 1969, the Convention Governing the Specific Aspects of Refugee Problem in Africa became the signature instrument that the OAU used to infuse some continental coordination into refugee governance. While subnational and state actors always insisted that Africa's refugee problem required homegrown measures, it was through the Convention that the states collectively articulated this position (OAU, 1969). Juggling decolonization, humanitarian action, and state building, the new leaders felt that Africa's refugee problem occurred in an environment so precarious that permanent solutions to them were possible only through the intellectual and organizational agency of African societies that have lived through the experience.

Insisting on African leadership also meant communicating this to international actors that wanted to operate or support action on the continent. This they did throughout the decolonization period at several conferences on African refugees. From 1967 to 1994, the OAU solely or jointly with the UN organized seven of these conferences, all attended by state donors, UN agencies, IGOs, and INGOs (SIAS, 1981). Some conferences, like the 1973 Oslo Conference on Southern African Refugees and the 1981 and 1984 Geneva International Conferences on Assistance to Refugees in Africa specifically targeted the international community for fundraising and to get their support for African initiatives (Chitego 1973; OAU, 1981). At these conferences, African representatives consistently demanded that international actors should play supportive roles under African leadership.

For instance, it was at the Oslo conference attended by 65 countries and 110 IGOs and INGOs, that African delegations insisted that the task of responding to humanitarian disasters in Africa belonged solely to Africans, and that "the role of the international community is supportive and complementary" to African leadership (Chitego 1973, 237). African representatives earlier expressed this at the 1967 Addis Ababa conference on refugees and later at Arusha 1979 and 1983, and Addis Ababa 1994. Archival records of the AU show that Africa made some of its strongest demands at the ICARA conferences where the OAU showcased proposals that its member states that hosted refugees had developed to support their appeal for international funding (OAU, 1981, 9, OAU, 1985, 1, 12). By educating the international community about their homegrown initiatives, the representatives' expectation was that the UN, INGOs, and other actors would fund but leave Africa actors to plan and deliver aid across the continent. However, as explained further below, the international community often responded to these demands with indifference, meaning that verbal endorsement of the OAU's initiatives did not always translate into practical support in ways Africans wanted.

What emerged from these initiatives was progress towards a homegrown system in the sense that it was started by people who were affected in the same physical spaces. Many community organizations started as schemes to help kinfolk separated by colonial borders, but as noted earlier, the initiators based their programs on self-determination, solidarity, and related communalist norms that they argued were innately African. Since the leaders from the outset instituted "African solidarity" and "burden sharing" as the bases for cooperation, homegrown actors across the various territories justified their acts by these principles (OAU, 1969). Based on these principles, independent states were expected to help refugees and those still under colonialism (OAU, 1963). Homegrown initiatives were therefore anticolonial both in their origin as reactions to colonial oppression and in their stated objective of removing the source of the problem.

Because of the massive population displacement caused by colonial oppression as well as by civil and interstate conflicts, much of Africa's initiatives were preoccupied with the issue of refugees. That said, there is not yet readily available data on how effectively these initiatives addressed the problem. However, in a 1967 study on the refugee problem in Africa, the Scandinavian Institute for African Studies concluded that "The solution to the problem of massive rural refugee groups seems to have been found. It consists of rural settlement in the country of asylum, i.e., in the creation of entirely new rural communities" (Hamrell $1967,10)$. As the trajectory of the refugee problem showed, this conclusion certainly did not mean that a final solution had been found. Besides, there were possibly other local factors that contributed to different levels of success across localities. However, coming at a time that most refugee assistance was delivered by African actors, this assessment was indicative of early successes that African actors achieved.

\section{INTERACTIONS BETWEEN AFRICAN AND INTERNATIONAL ACTORS}

Simultaneous to African the evolution of homegrown initiatives, international actors were arriving on the continent. A few like Save the Children and the ICRC had operated intermittently in Africa since 1931 and 1935, respectively, but it was during the decolonization era of the 1960s and 1970s that many started prospecting for opportunities on the continent. At the same time, the Economic Commission for Africa (ECA), UNICEF, and humanitarian actors like the UNHCR received UN mandates to help Africa's post-independence transformation. Because the nature of relations that developed between the internationals and African actors had implications for the latter, their priority was to create a relationship that would not compromise homegrown initiatives.

Initially, some international actors were equally cautious as anti-Western sentiments of the decolonization era slowed down any overly disruptive involvement. But so did the organizations' own limited budgets and little knowledge of Africa's contexts 
(Marrus 1985, 52, Rutinwa 2002). Some of the early research on interactions between homegrown actors and internationals show that the former remained in charge of decision making and aid delivery while international actors initially settled for "non-operational" statuses in which they functioned mainly as advisers and financiers (Daley 1989; Gasarasi 1984, 4). Humanitarian and development-oriented UN agencies like the UNHCR, UNDP, and the ECA played similar roles, as did members of global anticolonial blocs like the nonalignment movement. In some cases, funding and logistics brought by international actors initially boosted homegrown capacity as locals seized on opportunities to create more delivery structures (Kagwanja 2002, 97,; Amisi and Juma 2002). Some studies like Gasarasi (1984) and Juma and Surhke (2002b) for instance, describe the initial boost that international actors gave to homegrown ones as one of the highlights in this relationship.

Another way some international actors maintained this division of labor, was to ensure they did not overstep their original, single-issue mandates. However, sometimes, some organizations did this to the detriment of African actors. An example documented by an OAU report was in 1975 when each of the ICRC, International Federation of the Red Cross, and Lutheran World Federation declined the Africa's organization's request for suggestions and funding for the celebration of the OAU's maiden African Refugee Day. The internationals' excuse was that as organizations mandated to work only on prisoners of war and natural disasters, refugee issues were beyond their concern (OAU, 1975, 3, 6-7). These rejections however, were adamant because they came on the heels of longstanding complaints that some international actors took the division of labor too far (Matthews 1967, 98). In response to these, the ICRC had clarified that its "National Societies [were] auxiliaries to the public authorities in the humanitarian field and step in where social services are lacking" (ICRC, 2016, 11). These suggest that for a time, Africa boasted of a clear division of labor between homegrown and international actors, which gave local actors enough space to evolve.

However, funding was always a sticking point in Africa's homegrown initiatives and its relationship with international actors. Ideally, homegrown systems should be both selfinitiated, self-financed, and autonomous from external resources (Okereke and Agupusi 2015, 6). However, despite being wedded to their own norms and organizational structures, African aid organizations were almost always short of adequate funding to meet increasing needs. Many African states failed to sufficiently resource homegrown organizations within their territories. While the OAU verbally committed itself to achieving financial self-sufficiency, its own document shows that many member states defaulted on their dues, a situation which not only denied the organization of resources to implement programs but also defied its principle of African solutions for African problems (OAU, 1980, 1-6). In this context, it is reasonable to argue that by lessening the financial burden on homegrown organizations, international actors helped loosen a major constraint on the former's operations, but the result was that UN agencies and international NGOs became major funders of homegrown initiatives. By neglecting their financier roles, African states laid the foundations for financial dependence of homegrown actors on external resources. This means that the initial boost in homegrown capacity was neither complete nor sustainable.

\section{LOCALIZATION AND EROSION OF HOMEGROWN CAPACITY}

Despite initially finding division of labor and boosting Africa's homegrown capacity, the lasting impact of international humanitarian actors in Africa has been about how they helped erode that capacity through localization. Concerns about the erosion of Africa's homegrown initiatives have been explored in Juma and Suhrke edited volume Eroding Local Capacity: International Humanitarian Action in Africa which provides incisive accounts of how this process unfolded in different countries across Eastern Africa (Juma and Suhrke 2002a). Erosion as these studies found, meant that homegrown actors, their norms, and organizational structures lost their relative independence and were either subsumed under or replaced with those of international actors.

It is argued here that this erosion resulted in part from localization in the traditional sense, the process through which UN agencies and INGOs adapted their operations to Africa. In order to center the erosive effects of UN agencies and international NGOs on African homegrown capacity, it is important to draw attention to power, both discursive and material. This paper's position is that power in this sense must be historicized in global context, specifically that the erosion of homegrown capacity occurred during the long transition period in the international system when colonialism as a relational structure between Africa and Western countries was being replaced with global multilateral institutions and today's aid industry. As previous research has found, international humanitarian actors entered Africa in an advantageous position because they inherited the political, economic, and normative systems that colonialism had prepared for them in African societies (Rostis 2016, 17, 53, Skinner and Lester 2012, 741). In this sense, it has been argued that most impacts that the UN and INGOs have on Africa must be considered as joint efforts between colonialism and the international humanitarian system (Mubiala 1989, 93). Based on these findings, the argument can be made that international humanitarian actors that entered Africa must be considered a part of this structural transition from colonialism to the liberal international order in which the former had prepared African territories for the latter.

This means that even while initially restraining themselves from mounting full scale assistance programs, international actors always benefitted from inherent resource and structural advantages that eventually greased their path to dominating African spaces. However, this does not necessarily assume that international actors operated with sinister motives. In fact, whenever international actors used this advantage, it was often in response to factors that 
necessitated them. Across the decolonization period, the UN rapidly gave new geographical mandates to its agencies to assist states transition from colonialism to independence. Also, the $\mathrm{UN}$ took interest in the refugee problem in the face of the weakening financial positions of African actors and their limited capacities (UNHCR, 2000). By the early 1970s, it had become obvious that the division of labor that kept international involvement to a minimum was unfit for the purpose of meeting increased humanitarian needs.

As African actors searched for more systematic ways to respond to these changes and integrate international delivery capacity into African localities, Tanzania, Uganda, Botswana, and Zambia settled on the "tripartite arrangement" which they negotiated with UN agencies and INGOs. According to research on this period, such arrangements were meant to rope in more international capacity into the planning and delivery of aid in ways that did not encroach on the evolving homegrown structures. African states, therefore, insisted and got their partners to agree to design the arrangements on the principle of homegrown leadership (Daley 1989, 214, Gasarasi 1984, 24). These arrangements therefore came as temporary structures in which state authorities gave general policy direction, while UN agencies, INGOs and their local branches provided funding and technical support to homegrown actors, but now with more direct assistance programs of their own. But under the homegrown leadership principle, the parties agreed that international actors would step back after four to 5 years and hand over total control to the state (Gasarasi 1984, 19-20, Daley 1989, 227). Under tripartite arrangements therefore, the parties seemed to have found a way to meet emergency needs while homegrown actors built themselves to eventually take on full responsibilities.

Eventually, tripartite arrangements eased the localization processes of international actors' programs in Africa's humanitarian spaces by exploiting weaknesses in the homegrown initiatives. One such weakness was the lack of a growth agenda among homegrown actors. While justifiably preoccupied with responding to disasters within their own localities, it appears that most African actors during decolonization did not subscribe to a growth logic which would have seen them expand their operations beyond their territories of origin. By remaining small and mostly confined to their localities, they failed to exploit nationwide and transnational growth opportunities. But it is also realistic to acknowledge that the conditions they operated in did not lend themselves to growth chasing. For African actors that may have chased growth, it is reasonable to believe that their prospects of success would be slim due to the lack of funding for anything other than emergency assistance. Besides, the precarious political environment of decolonization must have made expansion beyond community and national localities impossible. Without a growth model, homegrown actors often rose and died with specific local disasters.

The lack of growth model among African actors sharply contrasted with the deliberate growth strategies that UN and INGOs pursued in Africa in their localization effort. Although respectful of the initial division of labor, internationals actors, from the outset, seemed intended to question and even undermine homegrown structures. Many started by questioning African humanitarian norms and organizational structures. After studying ICRC documents, Rostis found that in Central and Eastern Africa, the organization's delegations berated African groups for operating on a concept of solidarity that extended first and usually only to extended families and communities and not to affected people across borders. Blind to contextual dynamics and failing to admit that perhaps their internal principle of neutrality was not relevant to African localities, the delegations' racists interpretation was that Africans were intellectually and affectively not evolved enough to conceive of humanity beyond small social units (Rostis 2016, 74,76 ). Drawing on archival documents from the ICRC and MSF, Rostis' account provides incisive details into initial perceptions that officials of these international actors held about homegrown humanitarian actors and how such perceptions shaped their approach to interactions.

Similarly, the UNHCR in the early 1960s, far from any commitment it has made to strengthen African systems today, initially kicked against the OAU's program to create the African Refugee Convention that according to the African organization, was tailor-made for the peculiarities of handling refugee issues under decolonization and state building. According to an UHCR autobiography, the agency feared that an African instrument that adopted political solutions would lower the standards of protection for refugees and weaken the regional relevance of the UN's 1951 Refugee Act (UNHCR, 2000, 56). Therefore, where it happened, the erosion of homegrown capacities started with internationals' questioning how Africans thought about and designed their self-help programs.

What UNHCR and the ICRC considered normative vacuum or underdevelopment in Africa comes across as a misreading of the complex demands of the decolonization context, especially the necessity of using politics to address the root causes of refugee displacement. Nevertheless, international actors saw their duty as tutoring African organizations into 'acceptable' humanitarian standards, a process which since the 1970s has mimicked the civilizing missions of both European colonialism and missionary evangelism (Rostis 2016). In this sense, the global dissemination of the ICRC's humanitarian principles of neutrality, impartiality, and independence which have effectively undermined African principles like solidarity and political humanitarianism can be considered as evidence of the humanitarian civilizing mission. The fact that most African countries and regional organizations (ECOWAS, 2012; AU, 2015) have incorporated the ICRC's principles while sometimes understating homegrown principles in their humanitarian policies demonstrates the success of this mission.

However, localization went beyond just the verbal questioning of African norms and principles. Besides the agenda of international actors, the proactive investment in growth came on the back of several enabling factors. One was that consequent to acknowledging in the 1970s that the refugee displacement was now a long-term problem, international and homegrown actors started looking for more permanent solutions (Gasarasi 1984, 24). 
Also pushing the growth model was that by the 1970s, UN agencies and INGOs were being pressurized by donors to justify their continued existence and budgetary allocations (Kagwanja 2002, 285). These demands ignited in international actors a strategy to achieve concrete results and to establish more permanent presence on the continent.

Building permanent structures and presence across several countries became the strategy that international actors used to switch from non-operational roles to active involvement under tripartite arrangements, and to full aid delivery roles. Some observers have likened the growth logic that undergirded these developments by humanitarian organizations to business corporations known for "their ability to adapt to changing contexts and evolving markets" (Taithe and Borton 2016, 215). Starting from Bujumbura in Burundi, the UNHCR opened offices across Eastern and Central Africa, while the ICRC and Red Cross Societies rapidly opened societies in both active disaster zones and stable countries (Rutinwa 2002). As international actors expanded their operations, they faced the problem of how to structure their relations with African actors. Cooptation became a key route, but where homegrown actors resisted being co-opted, international actors sought or created better-funded local branches that often outcompeted the former out of existence (Harrell-Bond 1985, 9). It became common for homegrown structures to be subsumed under international actors.

It was found also that UN and INGOs made strategic use of opportunities that came with disasters. In this sense, they deployed "localization [as] an instrument for the unlocking of global market opportunities and an instrument of their globalization efforts" (Schaler 2009, 211). Each major disaster in Africa ended with international actors translating into practice their own principles and organizational logics, chipping away more power, aid delivery capacity, and more physical space from homegrown actors (Holland 2020, 15-17, Juma and Suhrke 2002a). Key among these was the Biafra conflict which is regarded as the defining disaster that expedited the expansion and consolidation of international capacities in Africa (Kuhn 2016, 325, O'Sullivan 2014). The Rwanda conflict provided a similar impetus in the 1990s (Storey 1997). However, civil wars, environmental disasters, and epidemics since the 1960s have provided the UN and INGOs endless opportunities to enter, create new projects, and introduce organizational structures that despite being good-intentioned, continued to eat away at African initiatives.

While the above account maps the general processes of how localization helped erode African homegrown structures, nothing crystalized the phenomenon more than how UN and INGOs came to dominate and run Africa's refugee camps. Tripartite arrangements played a dual role in this process because while they facilitated homegrown actors' access to funding and technical support in a coordinated manner, they became tools for internationals to increase their power and gain control over humanitarian installations like refugee settlements. Under these structures, some African states handed over control of refugee settlements to UN agencies and INGOs to manage on a temporary basis and passed legislations to formalize this change while national structures were being streamlined (Daley 1989,
214, 215). Therefore, it can be argued that just as colonies were testing grounds for modern European humanitarianism (Anderson et al., 2018), growth-chasing UN agencies and INGOs, though organizationally not mandated to hold physical territories, used refugee camps as grounds to test and perfect their models.

Subsequently, it was around the refugee camps that the relationship of subcontracting that continues to raise tensions between international and African actors evolved and became entrenched. To consolidate their control of refugee settlements, UNHCR backed by both international mandate and host government legislation, sometimes sacked most homegrown organizations from that place and retained a few as subcontractors (Kagwanja 2002, 101). Without operations in other countries, or even within other parts of the same countries, homegrowns organizations that were barred from refugee settlements had to either accept constricting contract terms with international organizations or close down (Kagwanja 2002; Rutinwa 2002). In their place emerged a community of international humanitarian organizations that could market to both donors and African governments not just their "expertise", but also the refugee camp as the most durable solution to displacement.

Given that humanitarian aid was an essential component of the decolonization order, one would think that governments of independent states would choose to fund and protect their homegrown organizations that were in this unequal fight with international actors. However, this was far from the case. Rather, localization's erosive impact on African organizations has been compared to local business entities that came under attack from multinationals without being protected by their government (Duffield 2001). In many countries, it was government policy that made homegrown actors vulnerable and created the conditions for their erosion. Many national governments provided little funding either because they did not belief in a free civil society, or because humanitarian funding was just prohibitive. For instance, after Tanzania briefly took control over its systems after the 5-year tenure of its tripartite arrangement, its estimated budgets in the 1980s was 178 million Shillings, slightly more that the budget for some government ministries (Gasarasi 1984, 25). This forced a return to an environment controlled by UN and INGOs. In many cases, tripartite arrangement metamorphosized into permanent control by international actors with little or no questions asked or any government attempt to reclaim them (Gasarasi 1984; Daley 1989). These left the systems in the hands of internationals as cash-trapped governments failed to sustain their own structures.

Additionally, government policy helped shrink the number of homegrown organizations. It has been found that there is a relationship between the type of political system and the expansion or shrinking of the number of homegrown humanitarian organizations (Rutinwa 2002, 82). Many governments co-opted homegrown actors and nationalized their operations but with no plans or capacity to sustain their operation. Others outrightly barred organizations from operating which forced a decline in the number of homegrown 
organizations while international actors and their local branches increased. For instance, at Kenya's independence in 1963, 30 of the 45 NGOs in the country were homegrown actors that delivered most aid. However, while the number of NGOs rose from 132 in 1978 to 267 by 1990, it was INGOs that rapidly multiplied while homegrown growth stagnated and then declined (Kagwanja 2002, 97). It has been found that this reversal of fortunes occurred because one-party states not only confiscated assets and co-opted operations of homegrown actors, but they also suppressed most civil society mobilization that governments deemed hostile to the state (ibid). These mean that when they encountered UN agencies and international NGOs, many homegrown actors, despite their discursive commitment to African peculiarities, were still struggling to find their feet and were not fit for competition even in their own backyard.

At the same time, localization, and the erosion it helped cause were subject to global economic and political forces that favored internationals actors. Not only did international humanitarian organizations inherit and build on the structural legacies of colonialism in their hold on territory and humanitarian civilizing mission, but they also remained linked to multilateral organizations and Western donors in powerful ways. This coalition, as noted by other studies, has often undermined homegrown humanitarian capacity (Skinner and Lester 2012, 732; Sewpaul 2016). Throughout the decolonization era, multilateral organizations like the UN consistently allocated and expanded the global mandate of its humanitarian agencies like the UNICEF and the UNHCR. As members of the UN, African states impliedly, approved such mandates, but the effect often meant that state agencies were outcompeted as mandates almost automatically elected international actors as the preferred channels for funding and aid delivery.

Preferential treatment for international actors has been symptomatic of the resource asymmetry between the West as saviors and the rest as suppliers of disasters. As has been argued, Western humanitarianism could not have attained its global dominance without Western cultural and material hegemony (Whittall 2015, 230-233, Wahab et al., 2012). Similarly, many of today's top international humanitarian organizations could not have survived past the 1950s without "investment" from their home governments (Taithe and Borton 2016, 215). This is because by electing their own aid agencies, Western donors assured them of constant cashflow and a head start when competing with cash-trapped African actors (Skinner and Lester 2012, 739). Even during the ICARA conferences where African states made some of their strongest cases for homegrown leadership, many donor states channeled resources only through their own agencies and made funding to African actors conditional on accepting subcontracting relationships with Western aid agencies (Daley 1989, 256-257). Ironically, it was after the supposedly pro-African ICARA conferences that the now pervasive practice of subcontracting became entrenched.

Not many things epitomize the localization of international operations and erosion of homegrown capacity more than the near banishment of the African state from humanitarian action. Based on the account above, an argument can be made that by the 1990s when Western African countries created refugee camps to host people fleeing wars in Liberia and Sierra Leone, the template was entrenched that UN and INGOs were the 'professional' managers for this, often with limited oversight from government and its agencies. Outside refugee camps, disease outbreaks, floods, and even industrial accidents were subjected to similar expert treatment by international actors.

The result has been either the self-isolation or side-lining of the African state from effective humanitarian leadership even within its own territory (Whittall 2015, 230-233, Daley 1989, i). The fact that some UN agencies and INGOs have access to more international capital, foreign exchange, material supplies, and political clout fortifies them from government influence and creates a system where they operate largely independent of their hosts (Daley 1989, 256-257). In many cases, UN and INGOs have effectively emasculated and replaced underresourced host government structures as aid deliverers that operate closest to the people, making the government only nominally present. The account above shows that what initially appeared to be a division of labor between homegrown actors and hesitant international organizations was certainly the calm before the erosion. After decades of pursuing growth, what resulted was the consolidation of a humanitarian regime that often prioritized organizational growth and survival as equally important as victim relief (Anderson et al., 2018, 15). It appeared that the success of humanitarian relief had become dependent on the survival of international actors.

\section{THE LIMITS OF "LOCALIZATION"}

As taken seriously in this paper, the account of how localization contributed to the erosion of African homegrown structures raises questions for the current process of localization. What needs questioning, especially, are the definitions of localization in the current process. If localization is taken to mean the process through which international actors adapt their operations to local contexts, then the contention of this paper is that this process has already happened over the past six decades. In recent historical accounts, one is more likely to read about globalisation of Western-originated organizations as one of the major changes in the humanitarian field since at least the 1980s (Barnett 2011; Everill and Kaplan 2013). However, a critical but less discussed component is what has been attempted in this paper, an account of how international actors established themselves on the grounds in those localities.

The above account of how African homegrown values and institutions got eroded provides this complementary perspective to the globalisation argument, by saying that the story of the humanitarian field over the same period has equally been about how international actors made themselves relevant in new territories through localization processes. In other words, the decisions and actions that resulted in the erosion of homegrown initiatives were indeed part of the processes of localization through which international organizations established their operations in Africa. Understood in this historical sense, 
localization of humanitarian action in Africa has already occurred and in an exclusionary way in which colonial-historical orders were structurally made to prevail over homegrown initiatives. Therefore, any further localization in this direction will be little more than giving a local face to international logics, ultimately to the further detriment of homegrown organizations.

As noted above, more reflective observers recognise the coloniality of foreign-led localization. However, the revision goes only as far as defining localization as the process through which homegrown actors adopt and adapt global norms and institutions to their own contexts. At first, this seems to be more inclusive because it replaces international actors with local actors as leaders of the process. However, except for the change in agency, this concept of localization is still problematic, first because the normative content that underlay it is still derived from outside of the context in which they are to be adapted. Second, like the first definition, this idea of localization has already taken place. This is evidenced, not least, by the fact that most African countries and regional organizations have incorporated the ICRC's humanitarian principles into their humanitarian policies even when they find these to be problematic. And, many governments, as noted earlier, gave international actors privileges that they denied their own homegrown organizations.

If localization proceeds in this manner by continuing the local adaptation of international templates over their own, it means that homegrown actors will be further internalizing and entrenching the sort of localization, exclusion, and selfsabotaging behaviors that left their own initiatives marginalized in the first place. That is, localization as process in which international or local actors lead the adaptation of international templates to local spaces is nothing new; it has already occurred. However, as a term, it has been recruited to deal with the problem it helped create without being redeemed from its erosive footprints. In short, the current localization agenda has yet to acknowledge the erosive footprints of similar historical processes. None of this is to question the necessity and legitimacy of the need to build humanitarian action on homegrown norms and institutions, or the role international actors can play in that process. Rather, the objective is to propose an alternative concept to localization that is more historically appropriate and tenable to frame the process of building homegrown humanitarian structures.

\section{RESTORATION OF HOMEGROWN INITIATIVES}

Despite having much of their initiatives eroded, African actors never abandoned the intention of creating and running their own humanitarian systems. In addition to national efforts to claw back some lost grounds, the OAU continued to push continental initiatives. Not daunted by the rejection they faced at all those conferences during the decolonization era, the organization in 1993 invited several African NGOs, UN agencies, and INGOs to a workshop in Ouagadougou aiming to create an African Humanitarian Initiative. The priority was to discuss why "for lack of an active presence, Africa which is assisted, is marginalized" (OAU, 1993, 1). Eight years later, a few months before the OAU was replaced with the AU, the organization held another conference, in Addis Ababa with the same mix of African and international organizations in attendance.

Describing the humanitarian scene on the continent as "a dismal setting", the OAU unleashed one of its harshest criticisms of humanitarian subcontracting, that "African NGOs are virtually powerless. They have become little more than hired hands supplying cheap labor for project-based aid. Capacity building, to the extent that it occurs, rarely aims higher than building a better subcontractor, in sum, a more "reliable" conduit of the latest aid concepts and resources" (OAU, 2001, 146). Both conferences ended with plans to create an African aid agency to coordinate the building of a homegrown structures at the subnational, national, and continental levels. While both processes stalled, the AU has since 2009 taken up the restoration process under its African Humanitarian Policy Framework.

It is because of this history-the evolution of African homegrown humanitarian initiatives, their erosion, and the ongoing attempts to rebuild-that any tendency to trace interest in homegrown capacity as a product of the 2016 WHS is wrong. However, the Summit was important because it was the first time that the major players decided to seriously listen to what African NGOs, states, and their regional organizations have been saying for decades. Additionally, the summit showed that it is the big players that determine which issue lands on the agenda and when it does. In this case, the account of how localization helped erode Africa's evolving homegrown structures raises questions for the current agenda because historical awareness is a necessary tool for some in the humanitarian field to overcome their preoccupation with the perpetual present (Borton 2016, 193-194, Taithe and Borton 2016, 211). UN, INGOs, and donors that are interested in supporting the creation of homegrown systems must therefore look back to history to first learn about how the problem they are dealing with came about, and second to appreciate their contribution to the problem.

Based on this historical awareness, this paper argues that the process of building humanitarian action on homegrown values and organizations should not be labelled as the historically erosive process localization but as a method for the restoration of the homegrown evolution that was eroded. Borrowed from the field of ecological planning, "restoration" is used to frame policies that aim to return the environment to a former state of affairs that with hindsight is considered better than the current state of affairs. Consistent with this general concept, restoration as used in this paper refers to "the process of assisting the recovery of an ecosystem that has been degraded, damaged, or destroyed" (SERI, 2004, 3). In ecological policy, restoration has for decades been used to frame responses to environmental damage from industrialization.

Under these processes, restoration entails not just historical repairs but also the lateral integration of solutions into current social, economic, and political ecosystems on a sustainable basis 
(Baker et al., 2014, 511). Temporality of restoration therefore is simultaneously backward-looking in correcting past mistakes, and forward-looking in ensuring that rebuilt systems are embedded in current and future development structures. Additionally, restoration is homegrown because leadership is provided by national authorities even if external players are partners (Agupusi and Okereke 2016, 4,13). At the same time, restoration is an exercise in sustainability because while addressing today's problems, it aims to prevent the recurrence of the same problem (Choi et al., 2008, 54-55). Ultimately, restoration processes aim to establish balance between the structures to be restored and their environment.

It is argued here that the process of building humanitarian action on homegrown structures must emulate the logic of ecological restoration that simultaneously aims at correcting historical mistakes and building balance with current cultural, economic, and political environments of African countries. It is noteworthy that in correcting historical mistakes, African countries are not going to restore complete and wellfunctioning homegrown structures; such structures were still evolving at the time they were eroded. This means that unlike ecological restoration, what must be restored in Africa is not some finished and self-sufficient humanitarian regime, but the process that was underway towards such a regime. Therefore, restoration in Africa is the process of returning homegrown actors to the track of evolution. While this might take decades to materialize, it is only through restoration that the agenda to build humanitarian action on homegrown structures can find the necessary long-term balance with the political and economic conditions on the continent.

As a process of building homegrown humanitarian structures, restoration can still be justified on the normative, strategic, emancipatory, and even on the structural adaptation grounds outlined earlier. However, restoring homegrown processes and seeking lateral balance requires certain normative and practical changes by both international and homegrown humanitarian actors. A fundamental requirement is for both international and homegrown actors to be guided by historical consciousness to mitigate the obsession with the present. Specifically, they should be interested in how their interactions over the decades have contributed to the erosion of homegrown capacities. If taken seriously, historical consciousness should guide them to avoid decisions and actions that created the problems on the table.

Guided by historical consciousness, restoration must proceed with the following components. At the core is homegrown leadership; it is African actors, not internationals, that should drive the process of restoration. By prioritizing NGOs based on the principles of neutrality and independence, the current localization agenda has almost certainly elected nonstate organizations as the drivers of the process. However, undefined is the role of host states. While some Western states are highly visible in the localization agenda, host states remain the elephants in the room. Several reasons have been proposed for this hesitation to rope in or even talk about host states, including fears that they will irredeemably politicize aid (Lautze et al., 2009; Kent 2011). While states in conflict simply lack the capacity and room to deliver aid, some are said to weaponize aid against adversaries and vulnerable populations, or are considered corrupt, incompetent, and too opaque to merit humanitarian leadership.

However, host state leadership is essential, and restoration cannot proceed without it. This is because just as we saw some African states create conditions that facilitated the erosion of their homegrown structures, the state can articulate a strategic vision and create the conducive environment for homegrown actors to thrive. That is, the grand mover that is needed to drive the process is found only in the capable, committed, and well-resourced state (Robillard et al., 2020, 10-13, 39). Evidence from other contexts, for instance, confirm this, that the state is indispensable to the building of homegrown structures (Sumaylo 2017; Baseisei et al., 2019). This means that towards restoration, African states must articulate a position for both historical and lateral restoration of homegrown humanitarian structures.

A second, related component of restoration, is that while the normative, strategic, structural, and emancipatory justifications for building homegrown systems remain valid in the restoration process, the broader underlying principle must change from humanitarianism to that of self-determination. In this way, restoration will do for the humanitarian field what decolonization did for politics. And, it will respond to calls for decolonization from the humanitarian field (Ncube 2020; Peace Direct 2021). Restoration, therefore, must be an exercise in decoloniality in which African actors led by the state take deliberate steps to decolonize humanitarianism by creating the intellectual bases for restoration with the recovery of homegrown concepts, principles, organizational, and operational structures that are better fitted to their own contexts and that do not readily copy sometimes misfitting external templates. Relatedly, since the decolonization that comes with restoration comes at a cost, African states and NGOs must take responsibility for the major sticking point in its relations with international actors, funding. As noted above, during the era of erosion, some international actors' refusal to fund homegrown actors, the redirection of funding from African channels to UN agencies and INGOs, and the failure of African actors to fill the gaps left perennial funding deficits that need to be filled for restoration to be truly independent. This means a self-initiated and self-funded system in which homegrown actors raise funds from sources like society, the private sector, the diaspora, and the state to mitigate the financial costs of self-determination.

Once homegrown actors have articulated a position based on self-determination, the third step will require the state to create a conducive environment for their own NGOs to emerge and thrive. African states must walk back the indifference and oppressive policies that contributed to the erosion of homegrown capacities. Now, they must create policies and agencies to oversee the development of homegrown NGOs that must be protected from unfair competition from international actors. There are several humanitarian operations that African actors can mount and successfully implement if they receive the right support from their state. A committed state should reserve certain geographical areas, issues, and resources for homegrown NGOs, and to the extent 
possible, keep the participation of international actors to a minimum.

Self-determination and decolonization do not necessarily mean banishment of UN agencies and INGOs from Africa. Afterall, restoration will take decades to materialize, and INGOs will play crucial roles in the process. Additionally, as they have many African states as members, UN agencies will continue to be relevant on the continent. However, by instituting self-determination, decolonizing aid, and financing their own programs, African states will be taking aim at the composite resource that has made international actors dominate the field, their power. As explained earlier, power in this case, is a resource that international humanitarian organizations partially inherited from colonialism. Over time, these actors became even more powerful as they became the preferred funding channels over homegrown organizations and received most resources that helped them shape the normative structures of the field in their favor. Such privilege is the sort of power that makes certain things possible and others impossible or unlikely (Quijano 2000). By restoring self-financed homegrown processes, African actors will diminish the precarity that they suffer when UN agencies and INGOs practice exclusionary practices like subcontracting.

But international actors, as said earlier will remain active in Africa in the foreseeable future. However, to be relevant to the restoration process, they must undertake the fourth set of steps. Here, they must trace and reconcile themselves with what can be called their "erosion footprint". This will be a record of how their localization processes over the decades have contributed to the erosion of homegrown capacity. Given the privileged status many of them have enjoyed since the 1960s, many UN agencies and INGOs likely have this footprint, and a dive into their archives should help them to understand how even their well-intentioned operations have historically helped erode African initiatives. As part of the process, they should attentively listen to what homegrown actors have been saying since the 1960s. After all, many of today's UN agencies and INGOs attended several of the humanitarian conferences throughout the decolonization era and are historically aware of Africa concerns about funding and subcontracting. International actors will do well to study African priorities and their own responses to these demands.

Especially important is the need for international actors to learn from their relationship with colonialism and understand the extent to which they benefit from and perpetuate colonial structures (Nicholas Borton 2016, 194, O’Sullivan et al., 2016, $3,10)$. In this sense, international actors are facing similar questions raised in critical development studies, especially as raised by Quijano's coloniality of power which argues that certain colonial practices after they became institutionalized, went on in the post-independence eras to discriminate against certain socio-political orders in favor of others (Quijano 2000). Related to this argument is that the discriminatory tendency of colonial legacies install power in the form of privileges, material resources, and access to mostly Western-originated organizations over homegrown actors (Atlani-Duault and Dozon, 2011; Hossain 2004). In this sense, power makes things possible and easy for selected actors in the field, while others do not have similar levels of access. In other words, international actors must look back and draw lessons for constructive engagement before they look forward.

Consequently, guided by reflection from their erosion footprint, international actors should ideally be the architects of their own redundancy in Africa's homegrown system. At the minimum, they must reproduce the restraint that some of them initially exercised in the 1960s and 1970s, but this time as a concrete organizational policy. More radically, international actors must phase out the relationship of subcontracting that has historically undercut homegrown efforts. As seen throughout the history and in the OAU's activism, subcontracting has been a source of tension between homegrown organizations and international actors. This changes when international actors acknowledge that they cannot be present everywhere (Vaux 2006, 245). This is even more so in a restored homegrown system. This means that they should adopt time-bound plans to fund homegrown organizations to flourish to be independent in the long-term and not keep them on the subcontracting leash.

In the process of restoration, both homegrown and international actors must rediscover physical territory as the fifth step. Like their evolution, localization and the erosion of African initiatives occurred in physical territories like refugee camps, villages, towns, and cities where UN and INGOs operated. Restoration must similarly be implemented in these physical territories. However, as explained above, the localization agenda has not clearly defined its relationship to physical territory, and one way some have tried to resolve this is through the idea of critical localism which claims that the local is not a physical place, but an abstract space of democratic exchanges among humanitarian actors (Mac Ginty 2015,842 , Roepstorff 2020,9). The fear of those who subscribe to this concept is that defining the local as a physical territory reinforces binaries and stereotypes about international and local actors. They contend also that in disaster situations, international and homegrown actors cannot be told apart. However, critical localism comes up against the longstanding international practices from colonialism to the contemporary globalizationlocalization divide which have always attached the local to physical space as a differentiating tool between the metropolis and the colony, between the territorial capital and its sub-units, and between the headquarters and the field (Chambers and Gillespie 2000). Since the 1960s at least, humanitarian actors built on this divide that attached locality to territory as Western organizations became global actors, and former colonies, the humanitarian local. Deterritorialization in humanitarian action, therefore, is historically inaccurate.

Additionally, this attempt to reconceptualize the humanitarian local as devoid of physical territory is problematic and is not suited to the restoration project. At the basis, critical localism ignores power as the exclusionary force behind the sort of localization that helped erode homegrown initiatives. As such, critical localism trivializes the lived suffering of people hammered by disasters in physical territories and not some abstract space where ideas flow. It also belittles the disadvantaged position of African actors that had their capacities eroded in those same territories under localization. Additionally, the suggestion that 
homegrown organizations cannot be told apart from local affiliates of international actors is questionable; even when they mix up to deliver aid, staff know which organizations are homegrown and which are local affiliates of international organizations. Also, by papering over significant power asymmetries between international actors and homegrown organizations, critical localism "perpetuates a real problem; it leaves a situation where local affiliates compete with indigenous ones for funding and crowd them out" (Ncube 2020). That is, for restoration to achieve its normative, strategic, and emancipatory purposes, pretending that power, privilege, and physical territories-factors that propelled erosive localization-are not relevant is exactly the strategy to avoid. Just as localization and the erosion of homegrown structures were territorialized, restoration must look to African actors in those same territories in Tanzania, Uganda, Kenya, and Botswana where their initiatives had been eroded. What restoration needs, therefore, is not less but more attention to physical territory.

It was explained earlier that one of the factors that contributed to the erosion of homegrown initiatives was the lack of a growth strategy by the African actors across territories. In a sixth step, restoration must fix this problem by pursuing growth. However, this is not necessarily a growth strategy by which African actors open local affiliates in other countries, but a method to find synergies with other restoration processes across the continent. Many of Africa's subregional organizations and the continental AU now boast of their own humanitarian policies and have initiated restoration processes of their own. State-led restoration inspired by self-determination must find organizational and operational synergies with these subregional and continental processes. In recent years, the continent's coordinated responses to the Ebola and the ongoing Covid-19 outbreaks suggest that synergies among African initiatives are desirable and possible. Synergies will not only facilitate the mobilization and sharing of resources but will also reinforce the mutual capacities of members and serve as protection for those that face crisis.

As explained earlier, restoration will ultimately thrive only under the leadership of African states. However, playing this central role in the restoration process requires a state to be politically stable in order to embed the process in its democratic systems, find continental synergies, and engage international actors in a sustainable way. This means that the restoration of homegrown processes will be an uneven process; states in conflict or with non-democratic systems will reasonably lag behind those that allow civil society organization. For humanitarians, the implication is that they must attend to a seventh component, stopping the compartmentalization of host societies and caring about the politics of the state as much as about strengthening the capacities of homegrown NGOs. Therefore, besides continuing to deliver emergency aid in conflict situations, humanitarians must participate in conflict resolution processes to help create a conducive political environment for restoration. Otherwise, the current strategy of strengthening the capacities of NGOs even in conflict zones would be nothing more than helping renovate a villa in the middle of a demolition zone; the villa's existence will be precarious. In short, restoration must aim at fostering a sustainable cordial relationship between NGOs and the state.

While the seven proposed components give restoration some ideas on how to proceed, restoring such structures will take decades. And it may not even happen especially if it gets caught in the current structural conditions. One is the failure to see not just a complement but an alternative to the current system; restoration will stall if African and international actors fail to imagine a homegrown humanitarian future. Besides, restoration will be expensive, which might scare some resource starved host states from wielding self-determination because of its costs. Additionally, African states may have to contend with degrees of resistance to restoration from some international actors. As noted earlier, undermining homegrown initiatives and resistance from some international actors have been part of erosive localization process. In this sense, asking international actors to exercise restraint, phase out subcontracting, and eventually orchestrate their own redundancies are difficult things to ask of actors that have built and dominated the current system for decades, and understandably have an interest in its continuation. Some recent studies have already noted varying levels of resistance from international actors to paradigm shifts in the humanitarian sector (Erdilmen and Ayesiga Sosthenes 2020; Pincock et al., 2020). However, African countries can overcome the resistances and even receive international backing if they have a clear enough and self-funded strategic plan for restoration. It all starts with imagining a homegrown humanitarian future.

\section{CONCLUSION}

Given that Africa's homegrown initiatives have historically been eroded, the current localization agenda cannot proceed as if nothing happened before. If not properly historicized, localization as currently termed refers to a different concept of building local capacity that has historically helped erode homegrown initiatives. Currently defined as anything from hiring local staff to structural adjustment, it will end up perpetuating the same problems it is trying to resolve if its historical application is not taken into consideration. An alternative concept, which is more sensitive to localization's history, is restoration. It is proposed based on the conviction that if the process of building homegrown capacity can be sustained over the long-term, international and homegrown actors must look back to embrace and learn from this history of how localization in its original meaning, and interactions between them helped erode African initiatives. Such historical awareness will help the actors avoid practices that caused the problem they are trying to solve. International organizations must identify and be guided by their erosion footprints, just as African actors need to be familiar with how they have been complicit in the erosion of their own initiatives.

Given the term's historical association with the erosion of African homegrown initiatives, it appears the humanitarian field has done a poor job at repurposing it for the current agenda. Restoration provides a more relevant perspective to both view this 
history and guide current and future action towards building homegrown structures. Restoration requires certain practical steps that not only stop further erosion but help resets the path to a homegrown humanitarian future. While international actors must exercise restraint, homegrown actors led by the stable state must articulate a position and lead the restoration process at the domestic and regional levels where the decades long processes of creating African-led systems continue.

Ultimately, restoration does a better job than localization at creating an endgame for the process of building homegrown structures. It creates a system in which Africans are not subcontractors or secondary players in their own lives but are the providers of the intellectual, organizational, and operational bases for humanitarian response in their own territories. With this endgame, international actors must be ready to play secondary roles that they have not been used to for a long time, just as African actors must lead the process in terms of policy, coordination, and funding. Restoration will not be a

\section{REFERENCES}

Acharya, A. (2004). How Ideas Spread: Whose Norms Matter? Norm Localization and Institutional Change in Asian Regionalism. Int. Organ. 58 (2), 239-275. doi:10.1017/s0020818304582024

African Union (2015). Humanitarian Policy Framework. Addis Ababa: African Union Commission.

Agupusi, P., and Okereke, C. (2016). Homegrown Development in Africa: Reality or Illusion? London: Routledge.

Amisi, B. K., and Juma, M. K. (2002). "Revitalising Relief Capacity as Part of the General Reconstruction Programme in Uganda," in Eroding Local Capacity: International Humanitarian Action in Africa. Editors M. K. Juma and A. Suhrke (Uppsala: Nordiska Africakainstitutet), 116-133.

Anderson, M., Becknell, K., and Taliano, J. (2018). "History of Humanitarian Emergencies," in Health in Humanitarian Emergencies: Principles and Practice for Public Health and Healthcare Practitioners. Editor D. Townes (Cambridge: Cambridge University Press), 9-24. doi:10.1017/9781107477261.003

Atlani-Duault, L., and Dozon, J.-P. (2011). Colonisation, développement, aide humanitaire. Pour une anthropologie de l'aide internationale. Ethnologie Française 41 (3), 393-403. doi:10.3917/ethn.113.0393

Baker, S., Eckerberg, K., and Zachrisson, A. (2014). Political Science and Ecological Restoration. Environ. Polit. 23 (3), 509-524. doi:10.1080/ 09644016.2013.835201

Barakat, S., and Milton, S. (2020). Localisation across the HumanitarianDevelopment-Peace Nexus. J. Peacebuilding Dev. 15 (2), 147-163. doi:10.1177/1542316620922805

Barbelet, V. (2018). As Local as Possible, as International as Necessary: Understanding Capacity and Complementarity in Humanitarian Action. London: Overseas Development Institute.

Barnett, M. N. (2011). Empire of Humanity: A History of Humanitarianism. Ithaca [u.a.]: Cornell Univ. Press.

Baseisei, M., Vani Catanasiga, F., Jirauni Josaia, O., Ilolahia, S., and Flint, J.Humanitarian Advisory Group (2019). Localisation in Fiji: Demonstrating Change. Suva, Fiji. Suva: Fiji Council of Social Services.

Brown, D., Donini, A., and Knox Clarke, P. (2014). Engagement of Crisis-Affected People in Humanitarian Action. Addis Ababa: ALNAP/ODI.

Capie, D. (2008). Localization as Resistance: The Contested Diffusion of Small Arms Norms in Southeast Asia. Security Dialogue 39 (6), 637-658. doi:10.1177/ 0967010608098213

Chambers, D. W., and Gillespie, R. (2000). Locality in the History of Science: Colonial Science, Technoscience, and Indigenous Knowledge. Osiris 15, 221-240. doi:10.1086/649328 uniform process across the continent. It will be mediated by factors like state capacity and the demeanor of international actors, so there will be top performers and laggards, but each needs to proceed at their own pace until they achieve homegrown self-sufficiency.

\section{DATA AVAILABILITY STATEMENT}

The original contributions presented in the study are included in the article/Supplementary Material, further inquiries can be directed to the corresponding author.

\section{AUTHOR CONTRIBUTIONS}

The idea for manuscript was conceived, researched, and written entirely by the present author $\mathrm{OB}$.

Chitego, H. (1973). "Speech: National Chairman of the Zimbabwe National African Union," in Southern Africa: OAU-UN Conference in Oslo (Uppsala: OAU).

Choi, Y. D., Temperton, V. M., Allen, E. B., Grootjans, A. P., Halassy, M., Hobbs, R. J., et al. (2008). Ecological Restoration for Future Sustainability in a Changing Environment. Ecoscience 15 (1), 53-64. doi:10.2980/1195-6860(2008)15[53: ERFFSI]2.0.CO;2

Daley, P. (1989). "Refugees and Underdevelopment in Africa: The Case of Barundi Refugees in Tanzania," in Doctor of Philosphy, the Faculty of Anthropology and Geography (Oxford: Oxford University).

Duffield, M. (2001). Global Governance and the New Wars. London: Zed Books.

Economic Community of West African States (2012). ECOWAS Humanitarian Policy. Aduja: ECOWAS Commission.

El Taraboulsi, S., James, S., and Gorgeu, R. (2016). Localisation in Humanitarian Practice. London: ODI/International Council of Voluntary Agencies.

Erdilmen, M., and Ayesiga Sosthenes, W. (2020). Opportunities and Challenges for Localization of Humanitarian Action in Tanzania. Ottawa: Local Engagement Refugee Research Network.

Everill, B., and Kaplan, J. (2013). The History and Practices of Humanitarian Intervention and Aid in Africa. London: Palgrave Macmillan.

Ezeanya-Esiobu, C. (2017). The Rise of Homegrown Ideas and Grassroots Voices: New Directions in Social Policy in Rwanda. Geneva: United Nations Research Institute for Social Development.

Gasarasi, C. P. (1984). The Tripartite Approach to the Resettiement and Integration of Rural Refugees in Tanzania. Uppsala: Scandinavian Institute for African Studies.

Gingerich, T. R., and Cohen, M. J. (2015). Turning the Humanitarian System on its Head: Saving Lives and Livelihoods by Strengthening Local Capacity and Shifting Leadership to Local Actors. Washington, DC: Oxfam America.

Hamrell, S. (1967). "The Problem of African Refugees," in Refugee Problems in Africa. Editor S. Hamrell (Uppsala: Scandinavian Institute for African Studies), 9-25.

Harrell-Bond, B. (1985). Humanitarianism in a Straitjacket. Afr. Aff. 84 (334), 3-14. doi:10.1093/oxfordjournals.afraf.a097674

Harris, J. E. (1987). Repatriates and Refugees in Colonial Society: The Case of Kenya. Washington, D.C.: Howard University Press.

Holland, E. M. (2020). The "Humanitarian Mystique:" Tracing the Rhetoric and Politics of Aid in Southeast Asia from the Age of the Civilizing Mission to the Present. Waterville, ME: Colby College.

Hossain, N. (2004). The Real-Life Relationship between Donors and Recipients in Bangladesh: Exploratory Research into the Sociology of Aid Relations.

International Committee of the Red Cross (2016). The Fundamental Principles of the Internatinoal Red Criss and Red Crescent Movement.

Juma, M. K., and Suhrke, A. (2002a). Eroding Local Capacity: International Humanitarian Action in Africa. Uppsala: Afrikainstitutet Nordiska. 
Juma, M. K., and Suhrke, A. (2002b). "Introduction," in Eroding Local Capacity: International Humanitarian Action in Africa. Editors M. K. Juma and A. Suhrke (Uppsala: Nordiska Afrikainstitutet), 5-15.

Kagwanja, P. M. (2002). "Strengthening Local Relief Capacity in Kenya: Challenges and Prospects," in Eroding Local Capacity: International Humanitarian Action in AfricaMonica Kathina Juma and Astri Suhrke (Uppsala: Nordiska Afrikainstutet), 94-115.

Kent, R. C. (2011). Planning from the Future: an Emerging Agenda. Int. Rev. Red Cross 93 (884), 939-963. doi:10.1017/S1816383112000331

Kuhn, K. J. (2016). "The Credibility of Our Humanitarian Efforts at Risk: Tensions between Solidarity and Humanitarian Aid in the Late 1960s," in Dilemmas of Humanitarian Aid in the Twentietch Century Edited by Johannes Paulmann (Oxford: Oxford University Press), 311-328.

Lautze, S., Raven-Roberts, A., and Erkineh, T. (2009). Humanitarian Governance in the New Millennium: An Ethiopian Case Study. London: Overseas Development Institute.

Mac Ginty, R. (2015). Where Is the Local? Critical Localism and Peacebuilding. Third World Q. 36 (5), 840-856. doi:10.1080/01436597.2015.1045482

Marrus, M. (1985). The Unwanted: European Refugees in the Twentieth Century. Oxford: Oxford University Press.

Matthews, Z. K. (1967). "The Role of Voluntary Organisations in the Refugee Situation in Africa," in Refugee Problems in Africa. Editor S. Hamrell (Uppsala: The Scandinavian Institute of African Studies), 97-109.

Melber, H. (2002). From Liberation Movements to Governments: On Political Culture in Southern Africa. Afr. Sociological Rev./Revue Africaine de Sociologie 6 (1), 161-172. doi:10.4314/asr.v6i1.23208

Metcalfe-Hough, V., Fenton, W., Willitts-King, B., and Spencer, A. (2020). Grand Bargain Annual Independent Report 2020: Executive Summary. London: Overseas Development Institute.

Mubiala, M. (1989). African States and the Promotion of Humanitarian Principles. Int. Rev. Red Cross 29 (269), 93-110. doi:10.1017/S0020860400072375

Ncube, A. (2020). Localization of Humanitarian Action: From Grand Bargain to Grand Betrayal. Available at: https://theglobal.blog/2020/09/09/localization-ofhumanitarian-action-from-grand-bargain-to-grand-betrayal/ (Accessed March 8, 2021).

Nicholas Borton, J. (2016). Improving the Use of History by the International Humanitarian Sector. Eur. Rev. Hist. Revue européenne d'histoire 23 (1-2), 193-209. doi:10.1080/13507486.2015.1121973

O'Sullivan, K., Hilton, M., and Fiori, J. (2016). Humanitarianisms in Context. Eur. Rev. Hist. Revue européenne d'histoire 23 (1-2), 1-15. doi:10.1080/ 13507486.2015 .1117422

O'Sullivan, K. (2014). Humanitarian Encounters: Biafra, NGOs and Imaginings of the Third World in Britain and Ireland, 1967-70. J. Genocide Res. 16 (2-3), 299-315. doi:10.1080/14623528.2014.936706

Okereke, C., and Agupusi, P. (2015). Homegrown Development in Africa: Reality or Illusion? New York, NY: Routledge.

Okereke, K. (2015). The Crises of Postcoloniality in Africa. Dakar: CODESRIA.

Organisation of African Unity (1963). Charter of the Organisation of African Unity. French: Addis Ababa: OAU.

Organisation of African Unity (1969). Convention Governing the Specific Aspects of Refugee Problems in Africa. French: Addis Ababa: OAU.

Organisation of African Unity (1993). Final Act of the Ouagadougou Symposium on the Need and Timeliness for an African Humanitarian Initiative. French: Addis Ababa: OAU.

Organisation of African Unity (2001). Report and Main Conclusions of the First OAU-Civil Society Conference. French: Addis Ababa: OAU.

Organisation of African Unity (1981). Report of the Secretary-General on the International Conference of Assistance to Refugees in Africa. French: Addis Ababa: OAU.

Organisation of African Unity (1985). Report of the Secretary-General on the Second Internatinoal Conference on Assistance to Refugees in Africa. French: Addis Ababa: OAU.

Organisation of African Unity (1980). Report of the Thirty-Fourth Ordinary Session of the Coordination Committee for the Liberation of Africa. French: Addis Ababa: OAU.

Organisation of African Unity (1975). Report on the Preparation of the African Refugee Day. French: Addis Ababa: OAU.
Peace Direct (2021). Time to Decolonise Aid: Insights and Lessons from a Global Consultation. London: Peace Direct.

Pincock, K., Betts, A., and Easton-Calabria, E. (2020). The Rhetoric and Reality of Localisation: Refugee-Led Organisations in Humanitarian Governance. J. Dev. Stud. 57, 719-734. doi:10.1080/00220388.2020.1802010

Quijano, A. (2000). Coloniality of Power and Eurocentrism in Latin America. Int. Sociol. 15 (2), 215-232. doi:10.1177/0268580900015002005

Robertson, R., and White, K. E. (2008). "What Is Globalization?" in The Blackwell Companion to Globalization. Editors G. Ritzer (Oxford: Oxford University Press), 54-66. doi:10.1002/9780470691939.ch2

Robillard, S., Jean, I., Gingerich, T., Esteban Meija, C., Farfan, L. B., Grisgraber, D., et al. (2020). Anchored in Local Reality: Case Studies on Local Humanitarian Action from Haiti, Colombia, and Iraq. Boston, MA: Feinstein International Center, Friedman School of Nutrition Science and Policy at Tufts University and Oxfam.

Roepstorff, K. (2020). A Call for Critical Reflection on the Localisation Agenda in Humanitarian Action. Third World Q. 41 (2), 284-301. doi:10.1080/ 01436597.2019 .1644160

Rostis, A. (2016). "Organizing Disaster: the Construction of Humanitarianism," in Critical Management Studies Critical Management Studies. First edition (Bingley, England: Emerald).

Rutihinda, C., and Elimimian, J. U. (2003). Globalization versus Localization of Global Marketing Strategy: The Case of Tanzania. J. Transnational Manag. Dev. 8 (1-2), 171-181. doi:10.1300/J130v08n01_09

Rutinwa, B. (2002). "The Marginalisation of Local Relief Capacity in Tanzania," in Eroding Local Capacity: International Humanitarian Actiton in Africa. Editors M. K. Juma and A. Suhrke (Uppsala: Nordiska Afrikainstitutet), 73-93.

Scandinavia Institute for African Studies (1981). The Recommendations from the Arusha Conference on the African Refugee Problem. Uppsala: The Scandinavian Institute of African Studies.

Schäler, R. (2009). "Localization and Translation," in Handbook of Translation Studies. Editors Y. Gambier and L. van Doorslaer (Amsterdam: John Benjamin's Publishing), 209-214.

Schuerkens, U. (2003). The Sociological and Anthropological Study of Globalization and Localization. Curr. Sociol. 51 (3-4), 209-222. doi:10.1177/ 0011392103051003004

Sewpaul, V. (2016). The West and the Rest Divide: Human Rights, Culture and Social Work. J. Hum. Rights Soc. Work 1 (1), 30-39. doi:10.1007/s41134-0160003-2

Shepherd, G. W. (1974). Humanitarian Assistance to Liberation Movements. Africa Today 21 (4), 75-87.

Skinner, R., and Lester, A. (2012). Humanitarianism and Empire: New Research Agendas. J. Imperial Commonw. Hist. 40 (5), 729-747. doi:10.1080/ 03086534.2012.730828

Society for Ecological Restoration International (2004). The SER International Primer on Ecological Restoration. Tucson, AZ: Society for Ecological Restoration International.

Storey, A. (1997). Non-neutral Humanitarianism: Ngos and the Rwanda Crisis. Dev. Pract. 7 (4), 384-394. doi:10.1080/09614529754170

Sumaylo, K. (2017). Local Humanitarian Action in Practice: Case Studies and Reflections of Local Humanitarian Actors. London: Humanitarian Leadership Academy.

Taithe, B., and Borton, J. (2016). History, Memory and 'lessons Learnt' for Humanitarian Practitioners. Eur. Rev. Hist. Revue européenne d'histoire 23 (1-2), 210-224. doi:10.1080/13507486.2015.1117426

Tandon, Y. (1984). Ugandan Refugees in Kenya: A Community of Enforced Selfreliance. Disasters 8 (4), 267-271. doi:10.1111/j.1467-7717.1984.tb00889.x

Tejumola, O. (2017). State and Culture in Postcolonial Africa: Enchantings. Bloomington: Indiana University Press.

United Nations High Commissioner for Refugees (2000). The State of the World's Refugees: Fifty Years of Humanitarian Action. Oxford: Oxford University Press.

Van Brabant, K., and Patel, S. (2018). Localisation in Practice: Emerging Indicators and Practical Recommendations. Switzerland: BegninsGlobal Mentoring Initiative.

Vaux, T. (2006). Humanitarian Trends and Dilemmas. Dev. Pract. 16 (3-4), 240-254. doi:10.1080/09614520600694653 
Wahab, E. O., Odunsi, S. O., and Ajiboye, O. E. (2012). Causes and Consequences of Rapid Erosion of Cultural Values in a Traditional African Society. J. Anthropol. 2012, 1-7. doi:10.1155/2012/327061

Wall, I., and Hedlund, K. (2016). Localisation and Locally-Led Crisis Response: A Literature Review. Bern: Swiss Agency for Development and Cooperation.

Whittall, J. (2015). A Crisis of Legitimacy for Humanitarianism: In Conflict Situations How Does the Close Relationship between Western Power and Humanitarian Aid Affect Emergency Response Capacity and Access for Aid Organisations?. Liverpool: Doctor of Philosophy, Liverpool School of Tropical Medicine.

Conflict of Interest: The author declares that the research was conducted in the absence of any commercial or financial relationships that could be construed as a potential conflict of interest.
Publisher's Note: All claims expressed in this article are solely those of the authors and do not necessarily represent those of their affiliated organizations, or those of the publisher, the editors and the reviewers. Any product that may be evaluated in this article, or claim that may be made by its manufacturer, is not guaranteed or endorsed by the publisher.

Copyright (c) 2021 Boateng. This is an open-access article distributed under the terms of the Creative Commons Attribution License (CC BY). The use, distribution or reproduction in other forums is permitted, provided the original author(s) and the copyright owner(s) are credited and that the original publication in this journal is cited, in accordance with accepted academic practice. No use, distribution or reproduction is permitted which does not comply with these terms. 